This is an electronic reprint of the original article. This reprint may differ from the original in pagination and typographic detail.

Author(s): Haapanen, Mika; Tervo, Hannu

Title: $\quad$ Migration of the highly educated: Evidence from residence spells of university graduates

Year: $\quad 2012$

Version:

Please cite the original version:

Haapanen, M., \& Tervo, H. (2012). Migration of the highly educated: Evidence from residence spells of university graduates. Journal of Regional Science, 52(4), 587-605. https://doi.org/10.1111/j.1467-9787.2011.00745.x

All material supplied via JYX is protected by copyright and other intellectual property rights, and duplication or sale of all or part of any of the repository collections is not permitted, except that material may be duplicated by you for your research use or educational purposes in electronic or print form. You must obtain permission for any other use. Electronic or print copies may not be offered, whether for sale or otherwise to anyone who is not an authorised user. 


\section{MIGRATION OF THE HIGHLY EDUCATED: EVIDENCE FROM RESIDENCE SPELLS OF UNIVERSITY GRADUATES*}

\section{Mika Haapanen}

School of Business and Economics, University of Jyväskylä, P.O. Box 35, FI-40014 Jyväskylä, Finland. E-mail: mika.p.haapanen@jyu.fi

\section{Hannu Tervo}

School of Business and Economics, University of Jyväskylä, P.O. Box 35, FI-40014 Jyväskylä, Finland. E-mail: hannu.t.tervo@jyu.fi

ABSTRACT. We examine the inter-regional migration of university graduates from 1991-2003 in Finland. The results show that time matters: two-years before and during the graduation year the hazard rates of migration increase, and then decrease thereafter. Although university graduates are particularly mobile, we find that most of them do not move from their region of studies within ten years after graduation. The out-migration, i.e., brain drain, is much higher among graduates in the more peripheral universities than in the growth centers (Helsinki in particular). Migration is also substantially more likely for those studying away from the home region than for those studying at home.

Keywords: Migration; higher education; university graduates; residence spells; return migration; onward migration; discrete-time duration analysis

JEL classification: J10; J61; I20; R23

\footnotetext{
* This study forms a part of the project "Higher education and regional economies" supported by the Academy of Finland (project 127049). We are very grateful to Mark Partridge and anonymous referees for their helpful comments. We have also benefited from comments at the Royal Economic Society 2010, EALE 2009 and Finnish Economic Association 2009 conferences, and "Population Dynamics in the Circumpolar North" workshop in Umeå 2008. Haapanen acknowledges financial support from the Yrjö Jahnsson Foundation for a visit at the University of Cambridge, 2009-2010 (project 6039).
} 


\section{INTRODUCTION}

In a knowledge economy, the most competitive regions are typically those with high levels of human capital, whereas the regions with low levels of human capital experience stagnant or slowing growth. Universities play a key role in bringing the human capital into regions. Regions with a university have a continuous flow of new tertiary-educated human capital and, thus, an advantage over other regions. It is unclear how well regions with universities succeed in maintaining this new human capital; do the graduates stay and for how long? The larger or more developed the local labor market area is, the more probable it is that the graduate stays, especially in large metropolitan areas. In a smaller university region, however, a graduate may develop location-specific human capital and stay in the area.

Understanding the migration patterns of university graduates is of particular importance because they represent a very mobile group of individuals. Despite this, relatively few

studies have been conducted recently. ${ }^{1}$ Studies in the United States ${ }^{2}$ have mainly focused on gaining a better understanding of 'brain drain', which results from outmigration of highly educated graduates from less developed regions. Because the highly educated migrants tend to possess above average skills and earn above average incomes, those who remain experience a higher tax burden and economic growth prospects weaken. A related line of research has focused on why 'smart cities', i.e., metropolitan areas with a large share of the adult population with a college degree, are growing in the US (see Winters, 2011).

In the United Kingdom, Faggian et al. (2006, 2007a, 2007b) and Faggian and McCann (2009) have investigated the sequential migration behavior of graduates. Jauhiainen (2010) has recently conducted a comparable analysis for Finland. In these analyses, the sequential migration behavior, to and from university, is classified into five distinct types. First, those who study at their home area may stay after education ('stayers') or 
move to work ('late movers'). Second, those who move to study may stay ('stickers'), or move back ('return migrants') or onward ${ }^{3}$ on leaving higher education. In addition, Venhorst et al. (2011) have recently analyzed trends in the spatial mobility of university and college graduates in the Netherlands.

A common drawback to these prior approaches is that they do not pay any attention to the fact that not all mobility takes place immediately after the graduation. In general, they do not reveal how migratory behavior develops over time, which is an important issue from the point of view of regional development.

The purpose of this paper is to consider mobility of university graduates from the viewpoint of residence duration. Three factors argue in favor of this viewpoint. First, the significance of 'brain drain' or 'brain gain' is likely to depend on how long the highly educated will stay in the region of graduation. To our knowledge, prior duration analysis is limited to Busch and Weigert (2010). ${ }^{4}$ Their results for Germany show that the longer an individual is observed to stay in the region where (s)he studied, the smaller the probability of migration in the future (so called negative duration dependence). Second, duration analysis enables us to study the importance of duration dependence relative to other factors explaining the migration decisions of graduates. However, contrary to Busch and Weigert (2010), our analyses reveal the hazard rates of migration $^{5}$ not only after graduation but also prior to it. Third, the results can be interpreted with theories of 'cumulative inertia' and 'cumulative stress' that are discussed in next section.

To study inter-regional and inter-individual differences in residence spells of university graduates, we differentiate between two groups of individuals: those studying in their home regions and those studying away from home. This distinction is important because their attachment to the region of studies is likely to differ (see DaVanzo, 1983; Faggian 
et al., 2007a). It also allows us to study onward and return migration hazard rates for the latter group. This comparison has been lacking from the published literature.

In the analysis, we utilize large longitudinal micro-data on Finnish university graduates from 1991 to 2003. Finland provides an appealing case for the study as it has a geographically extensive university network, but is now facing pressures to concentrate this network into fewer units. This policy change could potentially exacerbate the problem of brain drain from the outlying regions to the Helsinki metropolitan region.

The rest of the paper is organized as follows. The next section gives some background information on Finnish university system and presents the theoretical framework and hypotheses. In Section 3, we explain our discrete-time duration model for the analysis of residence spells. In Section 4, the data and variables are presented. The empirical results are discussed in Section 5. Concluding remarks bring the paper to an end.

\section{BACKGROUND: FINNISH UNIVERSITY SYSTEM AND GRADUATE LABOR MOBILITY}

\section{Universities and Studying in Finland}

The Finnish university system consists of 20 universities and art academies in 10 locations all of which carry out research and provide education, awarding degrees through the doctorate level. A geographically broad university network has been seen as means to equalize the regional development, for example, by reducing the brain drain from less developed regions. Ten of the universities in Finland are multidisciplinary, and ten are specialist institutions. The university system expanded from the 1960s to the 1980s, and it had a rapid growth in financial resources from the mid-1980s up to 1990.

For achieving regional policy goals, the regionalization of university education system to cover practically the whole country is very successful (Tervo, 2005). Especially the regions that succeeded in getting a university of their own have flourished. All these regional universities have attracted talented young people to pursue studies. Many of 
these universities have become hosts to important technological and research and development initiatives which have increased training opportunities and jobs in the regions concerned.

In the early 1990s, a severe recession slowed down development in the university sector, until it accelerated again in the late 1990s. Attention was focused on improving performance and quality of the university sector; see Ministry of Education (2005) for details. Recently, there has been a significant increasing trend in the number of graduates, and to lesser extent in financial resources, in nearly all Finnish universities (Ministry of Education, 2009). Nevertheless, the regional disparities in economic growth and unemployment rates have increased since the severe recession of the early 1990s; see e.g. Kangasharju and Pekkala (2004) and Tervo (2005). The university system is under more and more pressure to increase productivity and prioritize activities.

Today, there is also pressure to concentrate higher education and research into fewer units in Finland, which probably means a remarkable decrease in the number of universities and polytechnics in the future. If only university regions do well in the future, as has largely been the case until now, regional disparities would increase as a consequence of the consolidation of the universities. Ultimately, it is necessary to understand the migratory behavior of university graduates.

Finnish university degrees correspond to Bachelor's, Master's degrees and Doctorates. In the study period investigated in this paper, almost all students automatically studied for a Master's which corresponds to the Anglo-American Master's degree. Typically, students start their university studies at the median age of 21 (Saarenmaa et al., 2010, p. 31 , although there is much variation in this; the youngest are graduates from senior high schools, aged 18-19 years, and there is no limit for the oldest. The average duration of university studies is comparatively long in Finland, six to seven years in 
2003 (Ministry of Education, 2005, p. 21), which is largely because many students work part-time. ${ }^{6}$ One can graduate at any time of the year, although graduation occurs more frequently in the springtime. The Finnish university system makes it possible to finish up the studies outside the study place if all the compulsory courses that require attendance have been completed. For this reason, we also analyze pre-graduation migration.

\section{Theoretical Considerations about Residence Spells and Migration}

Two forces operate in the opposite direction during the residence spells of graduates; see Huff and Clark (1978), Molho (1995) and Gordon and Molho (1995). On the one hand, attachments to home, friends, and area of residence increase over time because social networks develop and local human capital accumulates. This hypothesis is referred to as 'cumulative inertia'. Thus, the propensity to move may decrease gradually over the course of a residence spell.

On the other hand, migration may become more likely as individuals' graduation approaches, because the graduating students will begin searching for optimal employment in a broader geographical area. This is the 'cumulative stress' hypothesis. In addition, stress may arise later in the residence spell if individuals become increasingly dissatisfied with their living situation in the current location over time, perhaps reflecting a progression through their life-cycle or career. ${ }^{7}$ We would also expect from both theory (DaVanzo, 1983) and empirical data (Faggian et al., 2007a) that those studying away from home have a higher conditional migration propensity and shorter residence spells.

In addition to these forces, other factors, such as the personal, household and labor market characteristics will affect the migration decisions of the graduates over their residence spells; see e.g. human-capital theory (Sjaastad, 1962) and job-search theory (Herzog et al., 1993). The effects of gender, age and the level of education on the 
migration decisions are often investigated, but studies have rarely been able to control for field of education; see, however, Gottlieb and Joseph (2006) and Faggian et al. (2007a).

Family $^{8}$ ties (Mincer, 1978) and home ownership (Helderman et al., 2006) discourage migration, but little is known whether these household factors have a similar influence on all migration decisions. Newbold (2001, p. 35) found that married (and the highly educated) individuals are less likely to return to their previous province of residence. Personal and regional unemployment, and low financial assets, may encourage migration as a result of job seeking and a lower attachment to the local labor market (Pissarides and Wadsworth, 1989; Tervo, 2000; Haapanen and Ritsilä, 2007). Commuting to work shorten the duration of the residence spell (Romani et al., 2003).

Finally, graduates from different regions of origin are likely to exhibit different repeat migration patterns (cf. DaVanzo, 1983). Specifically, we expect that graduates originating from regions with promising labor market opportunities are more likely to move back, whereas others are more likely to either stay in the university's region or move on. In addition, return (onward) migration is likely to be a negative (positive) function of the distance moved to the university location from the home region.

\section{MODEL}

To model the determinants of residence duration, we need a measure for the probability of migration in the subsequent period given that an individual has been living in the current region (survived) up to the current period, i.e., the hazard rate of migration. If we could observe the exact length of the residence spell of individual $i$, then the continuous time hazard function could be parameterized by using a proportional hazard specification: ${ }^{9}$

$$
\theta_{i}(t)=\lambda(t) \cdot \mathrm{e}^{\beta^{\prime} \mathbf{x}_{i}(t)},
$$


where $\lambda(t)$ is a baseline hazard at time $t, \mathbf{X}_{i}(t)$ is a vector of (time-varying) covariates, and $\boldsymbol{\beta}$ is a vector of unknown parameters to be estimated with Cox regression (see e.g. Wooldridge, 2002, Ch. 20). However, the duration data available to us are interval censored. No information on the precise timing of migration is included because the status of a residence spell is only observed at the end of each year. Therefore, discretetime model consistent with a continuous time model and interval-censored survival data is specified; see Prentice and Gloeckler (1978) and Sueyoshi (1995).

Suppose that $T_{i}$ is the actual (unobserved) length of a residence spell of individual $i$. Then the discrete interval hazard rate, the probability of a spell being completed by time $t+1$, given that it was still continuing at time $t$, can be defined as:

(2) $\quad h_{i}(t)=\operatorname{prob}\left(T_{i}<t+1 \mid T_{i} \geq t\right)=1-\exp \left[-\exp \left(\boldsymbol{\beta}^{\prime} \mathbf{X}_{i}(t)+\alpha(t)\right)\right], t=-2,-1,0,1, \mathrm{~K}$

where time $t$ is indexed relative to the graduation year (i.e., $t=0$ when a student graduates), function $\alpha(t)$ summarizes the pattern of duration dependence in the interval hazards, $h_{i}(t)$, and the hazard rate is specified by a complementary log-log distribution.

A semi-parametric baseline hazard is assumed for the first six intervals, allowing the baseline to vary freely with duration time $t$; see e.g. Meyer (1990). In practice, an indicator variable, $\alpha_{t}$, per duration time $t$ is added. For the latter intervals, a simpler logarithmic baseline function is assumed due to low number of observations (see Table 2 below):

$$
\alpha(t)=\left\{\begin{array}{c}
\alpha_{t} \quad \text { if }-2 \leq t \leq 3 \\
\gamma_{0}+\gamma_{1} \ln (t-3) \text { if } t>3
\end{array}\right.
$$

where $\gamma_{0}, \gamma_{1}$ and $\alpha_{t}$ are the estimated parameters. If the values of $\alpha(t)$ decrease as a residence spell gets longer, it would imply a decreasing propensity of migration over the course of the spell (negative duration dependence). That is, cumulative inertia is 
dominating over cumulative stress. Similarly, if $\alpha(t)$ is an increasing function of $t$, it would imply positive duration dependence.

The models are estimated separately for those living in their home region and those studying away from home. However, we have assumed only one exit state: outmigration terminates the residence spell. This assumption is reasonable for those studying at home because they have only two options, to be the 'stayer' or 'late mover'. But for those studying away from home, we need to allow for competing risks of either returning home or moving onwards, as against being a 'sticker' (cf. Faggian et al., 2007a, 2007b). The distinction is potentially important, because individuals' behavior may differ with respect to these two risks. The pattern of duration dependence may also differ between the two. Hence, the model is extended to allow for these competing risks, and separate parameters $\left(\boldsymbol{\beta}, \alpha_{t}, \gamma_{0}, \gamma_{1}\right)$ will be estimated. In practice, the parameters of a cause-specific hazard can be estimated by treating duration finishing for other reasons as censored as the point of completion (Narendranathan and Stewart, 1993).

One potential problem remains: some covariates could be missing from our model. We do not have, for example, direct measures for the 'tastes' or motives for mobility. The presence of such unobserved individual effects, correlated over time, can result in an overestimation of the negative duration dependence and an underestimation of the $\boldsymbol{\beta}$ 's; see e.g. van den Berg (2001). To test for neglected heterogeneity, we will try a generalized version of the model, where unobserved individual effects are assumed to be normally distributed.

For brevity, we do not, however, consider the initial decision to move for higher education, although it is recognized that those studying at home and away are two distinctive groups of people. Hence, our results should be interpreted as conditional propensities to move, i.e., conditional on studying at home or studying away. Finally, to investigate how the pattern of duration dependence differs between the graduates from 
Helsinki region and other university regions, the models are later estimated separately for these two groups of people.

\section{DATA AND VARIABLES}

\section{Data}

Our data are based on a Longitudinal Census File and a Longitudinal Employment Statistics File constructed by Statistics Finland. These two basic files were updated annually from 1987 until 2004. By matching individuals' unique personal identifiers across the censuses, these panel data sets provide a variety of information on the residents of Finland. In addition, data on spouses and region of residence can be merged with the individual records. The location-specific characteristics are measured at the regional level (NUTS3) or at the sub-regional level (NUTS4).

Herein, migration is defined as a long-distance migration between the 19 NUTS3 regions (labor market areas). Migration of shorter distances between municipalities or sub-regions would more likely be explained through housing market changes. The longdistance migration also allows us to investigate changes in the geographical distribution of human capital in Finland. Studying long-distance migration is also practical, because the location of educational institutions is identified at the regional level in the data.

For this study we took a seven percent random sample of the individuals who resided permanently in Finland in 2001. The working sample was further restricted on the following grounds. First, only individuals graduating from their first tertiary educational institution (i.e., getting a Master's degree from a university) in 1991-2003 were selected for the analysis. By focusing on these graduates, we are able to distinguish most labor market moves, which are the focus of our study, from the moves related to acquiring educational qualifications. Second, we only consider individuals who were less than 35 years old when they completed their university degree. For older individuals, data 
limitations would have made it difficult to rule out prior educational qualifications. This restriction also increases homogeneity of our sample.

Third, we only selected individuals who were actually living in the region where their university is located. The best solution for the data reliability is to leave out those graduates whose registered place of residence three years before graduation is not equal to the region where their university is located. We also conducted the analyses with the whole data set and found that the results were largely alike.

Thus, the analysis is based on samples from 13 cohorts of graduates between 1991 and 2003, with a follow-up period that begins three years prior to graduation. ${ }^{10}$ An individual's residence spell is monitored until (s)he moves away from the region of studies, the last year of observation being 2004. Consequently, the maximum observed duration of 16 years means that the data is possibly right-censored for the residence period. Because an observed residence spell may start after 1988, some spells are rightcensored at shorter duration. The sample restricted in this way yields 4,373 residence spells (individuals) and results in 31,813 spell-year observations. A total of 2,699 individuals were studying in their home region and 1,674 were studying away from home three years prior to their graduation. Here, "home" is defined as the NUTS3 region, where the individual was living at the age of 18 years. ${ }^{11}$ This familiar region is also referred to as "origin".

\section{Explanatory Variables}

Table 1 describes our explanatory variables $X$. Most of the variables are treated as timevarying; their values can vary over the course of the spell, because the situation immediately prior to the annual migration decision is likely to carry more weight in the individual's prediction of the future than that at the very beginning of the residence spell. The measurements of the explanatory variables relate to the year before the 
decision to move is made, so that the consequences of migration are not confused with the causes of migration.

In addition to personal, household and labor market characteristics, ten location of residence dummy variables are used, with the Helsinki region as the reference (NUTS3 classification). These dummies capture effects unexplained by the other regional factors discussed above, including natural amenities (Rickman and Rickman, forthcoming) and those specific to an individual's university. Origin-specific variables have been included to measure the attractiveness of the home region for those individuals who have studied in a university out of their home region. Finally, year dummy variables are used to capture annual changes in migration propensity because inter-regional mobility tends to follow cyclical trends in the economy (Milne, 1993; Pekkala and Tervo, 2002; Venhorst et al., 2011).

\section{-- Table 1 around here --}

\section{RESULTS}

\section{Descriptive Analysis}

Table 2 presents life-table estimates of residence survival rates ${ }^{12}$ and hazard rates of migration by origin. Conditional on living in the region of studies three years before graduation, the propensity to move in the following year is approximately 1.4 percent for those studying at home, and close to 5 percent for the others. In both cases, the hazard rate of migration increases in the following two years, and peaks at the graduation year at 7.6 percent for those studying at home and 18.7 percent for those studying away. Cumulative stress caused by the graduation seems to dominate the effect of cumulative inertia. In the latter intervals, however, cumulative inertia dominates; the hazard rates decrease quickly as residence periods get longer and are only 1-2 percent during the last intervals. ${ }^{13}$ Second, a comparison of the estimated survival functions with a log-rank test indicates a statistically significant difference between those 
studying at home and away. Finally, Table 2 reveals no clear changes in the proportion of migrants returning home over the course of the spell.

-- Table 2 around here --

Table 3 displays survival rates for Helsinki and other university regions separately. The regional differences are significant. ${ }^{14}$ Of those graduates who have been studying in their home region Helsinki, over 90 percent are still living in this capital region five years after their graduation. The corresponding average figure for the other regions is 61 percent. Helsinki region is also able to keep its graduating students even if they have not grown up in the region. Of those studying away from home in Helsinki region, 71.5 percent still reside there five years after graduation. The corresponding figure for other regions is much lower (on average around 37 percent). Therefore, the contribution of the local university graduates to local economy is much stronger in the Helsinki region than in the peripheral university regions.

-- Table 3 around here --

In their paper about graduate human capital mobility in Britain, Faggian and McCann (2009) present figures about the proportion of locally educated university graduates who remain in the same NUTS1 region as their university for employment after graduation. A direct comparison to our figures is difficult because the British figures in Faggian and McCann (2009) represent a combination of those graduates who studied in their home region as well of those who studied away from home. It seems, nevertheless, that the graduation retention rates are smaller in Britain than in Finland; the retention rates varied from approximately 70 percent (London) to 40-44 percent (Yorkshire and the Humber). This interesting finding calls for a more detailed analysis.

\section{Estimation Results}

Although informative, descriptive analyses do not reveal the factors at work. Therefore, the results obtained from the discrete-time hazard models are presented in Table 4 . The 
models have been estimated separately for those graduates studying in their home region and for those studying away from home. For the latter group, the results of a competing risks model of return and onward migration is presented. Diagnostics reported at the bottom of Table 4 imply that these specifications are not rejected by the random effects models that control for individual-level unobserved heterogeneity. The $p$-values of the likelihood ratio tests are all greater than 0.10 .

-- Table 4 around here --

The preceding descriptive analysis based on the follow-up life-tables suggested substantial differences in the hazard rates of migration between those studying at home and away, as well as regional differences between universities. Our econometric models allow us to investigate whether this result still holds after all the personal, household and labor market characteristics, and region-specific factors have been controlled for. To compare the evolution of hazard rates of migration over the course of residence spells, we have computed average hazard rates for the university graduates studying at home and away ${ }^{15}$ (Figure 1).

Figure 1 (a) shows that the average hazard rates of migration increase rapidly before graduation. Cumulative stress triggered by the approaching graduation seems to dominate the cumulative inertia. After graduation the hazard rates drop rapidly. Cumulative inertia begins to dominate. For those studying away from home the rise and fall of the hazard rates of migration is particularly large close the graduation year. Differences between the average hazard rates of migration for these studying at home and away are statistically significant until the year after graduation. Similarly, Figure 1 (b) shows the average hazard rates of onward and return migration separately for the graduates studying away from home. Although the shapes of the hazard functions are fairly similar, a close comparison of the hazard functions suggests that immediately 
after graduation individuals are relatively more willing to move to unfamiliar regions than they are a couple of years later.

-- Figure 1 around here --

Next we consider the importance of other factors in our model, such as the personal, household and labor market characteristics that shift the hazard curves proportionally up or down. Most findings are in line with expectations and other studies, while some of them are new or contradictory and need further elaboration. For brevity, we will focus on the latter.

In almost all fields of study, hazard rates of migration are bigger than in the reference field, technology and natural sciences. Technical training is given in many universities, for which reason the net benefits of moving are comparatively small for these graduates. They are therefore often non-movers or stickers. On the contrary, graduates with health, welfare or sports education have high migration rates, regardless of whether they study home or away. This finding is as expected because such training is only given in few universities (e.g. sports education only in Jyväskylä), but not all graduating students can obtain job from their study region.

For those studying away from home, spouse's employment discourages onward migration but not return migration. Both migration decisions could mean that the employed spouse has to give-up a job, but our results hint on that the employed spouse is more willing to move to a familiar location (from where the spouse perhaps also originates) than to a new region. For those studying at home, migration rates also decrease with spouse's labor income and increase along with his or her educational level. Interestingly, an individual's propensity to return home increases significantly prior to children entering school (i.e., all under 7 years). ${ }^{16}$

In terms of labor market matching, it is encouraging to see that unemployed persons and those out of labor force are more likely to move than employed persons. In contrast to 
personal unemployment, regional unemployment rate only increases likelihood of return migration. Thus, onward and return migration respond differently to the personal unemployment experience and to the risk of unemployment a graduate faces (in terms of regional unemployment).

Looking at those studying at their home region, graduates from Helsinki's universities have much lower propensity to move than the graduates from other universities, even after controlling for other factors. Graduates from Lappeenranta and Rovaniemi have particularly high propensity to leave their home region after graduation, but the migration rates are also high in Joensuu and Jyväskylä. These findings are likely to reflect the adverse employment prospects in these regions. In the case of onward migration, regional differences are again marked; Helsinki is best able to retain its graduates. Return migration rates do not differ as much between the regions, and the only significant difference is between graduates from Helsinki and Vaasa regions.

With regard to the region of origin, onward migration (instead of return migration) is very likely for those originating from Itä-Uusimaa. This result is expected because ItäUusimaa is located next to the capital Helsinki. Return migration is also very unlikely for those originating from Kanta-Häme, which is neighboring the attractive labor market areas of Helsinki and Tampere. Return migration to Keski-Pohjanmaa (neighboring Vaasa) is also unlikely. Both these regions do not have a university. Consistent with Faggian et al. (2007b), distance moved to educational institution in the past does have a positive effect on onward migration. In sum, the highly educated are moving from regions with less promising labor market opportunities to expanding regions (cf. Ritsilä and Haapanen, 2003; Tervo, 2005).

\section{Comparison of Helsinki Metropolitan Region with Other Regions}

To further highlight the importance of the Helsinki metropolitan region, we have estimated the above models separately for those graduates living in Helsinki and for 
those living in the other university regions. ${ }^{17}$ The separate estimates allow us to compute average hazard rates of migration for these specific university graduates. These migration rates are illustrated with Figure 2 and 3.

-- Figure 2 around here --

-- Figure 3 around here -

As expected, the hazard rates of migration are lower in the Helsinki region than in the other regions (Figure 2 and 3). In all cases hazard rates of migration are very low for those residing in the same region a decade after graduation. However, the figures also show differences in the duration dependence. Firstly, from two years after graduation, the hazard rates of migration remain relatively constant over time (and low) in the Helsinki region, whereas the propensity to migrate remains high after graduation in other regions for several years, but drops over time (Figure 2).

Secondly, and interestingly, for those studying at home in the Helsinki region, hazard rates do not respond as sharply to graduation as they do in all other cases (cf. also Figure 3). Thus, particularly in Helsinki, graduation seems to affect migration propensities more for those studying away from home than for those studying in their home region. Finally, in regions outside Helsinki, it is noticeable that onward migration responds significantly more to university graduation than return migration (Figure 3).

These separate estimations also tell us more about what (regional) characteristics tend to concentrate university graduates in the Helsinki metropolitan region. We find that, for those studying in Helsinki, the longer distance they moved for the university, the less likely they are to return to their home region after graduating. This effect is strong. After controlling for differences in the distances moved, Vaasa and Oulu are able to attract graduating students from Helsinki relatively better than the other regions. For those studying outside Helsinki, the propensity to move increases with personal and regional unemployment. Ceteris paribus, graduates originating from Helsinki are not 
exceptionally likely to return to their home region after studies. Commuting predicts future migration for those individuals graduating from universities outside Helsinki, but not for those graduating from universities within Helsinki. The results are consistent with Christiadi and Cushing (2008) who find that the demand for an individual's occupational skills is important when making the decision to move to slow-growth regions, but relatively unimportant for high-growth regions.

\section{CONCLUSIONS}

This paper examines the migration behavior of a very mobile population group, young educated adults. This group is of vital importance from the point of view of human capital accumulation and positive development in peripheral regions. While it is clear from priori literature that the highly educated are particularly eager to move, much less is known on how their migration propensities change over time. The question is important because the longer the graduates stay, the longer they can foster economic development and growth in the region where they graduate from. Thus, our focus is on university-leaving step and the length of time graduates remain in their university localities.

We learned that time matters. Before graduation the hazard rates of migration increase rapidly. Cumulative stress triggered by the graduation from university seems to dominate the cumulative inertia. Hazard rates drop fast thereafter, and cumulative inertia begins to dominate. This type of duration dependence is found not only for those who study at their home region, but also for those who are studying away from home and are contemplating return and onward migration.

Although university graduates are particularly mobile, we find, contrary to what Faggian et al. (2007a) and Faggian and McCann (2009) found from Britain, that most of them do not move from their region of studies within ten years after graduation. Hence, they have an effect on their region of graduation. However, the amount is likely to differ 
across regions. The out-migration, i.e., brain drain, is much higher among graduates in the more peripheral universities (e.g. Lappeenranta, Joensuu and Rovaniemi) than in the growth centers (Helsinki in particular). In addition, there is much inter-individual variation in the migration patterns based on an individual's location of origin. Graduates studying in their home region have much lower propensity to move than those living away from home.

From a policy point of view, understanding mobility of graduating students is important in Finland due to plans to concentrate higher education into fewer places. A geographically broad university network (i.e., access to university in a home region) may, at least to some extent, hinder out-migration and contribute to more equal regional development. Our findings point to the increasing danger of the concentration of human capital embedded in graduates. As the issue of developing peripheral regions is more relevant for Finland than for many other countries, the plans to concentrate higher education may prove to increasingly steer development towards centralized human capital and economical structures. The results especially refer to the possibility that the Helsinki metropolitan area mushrooms. But then again, if the marginal returns for university graduates in Helsinki are higher due to agglomeration economies, this economic gain may offset any loss in regional development goals.

Our analysis provides important information on the effect of education on regional redistribution of human capital. A complete picture would, of course, require an analysis of all possible locational adjustment characteristics of young adulthood, i.e., an analysis of moves related to exploring, finding careers, and forming a family (cf. Plane and Jurjevich, 2009). For the regions without a university, an important question is how well they are able to tempt graduates to move into their region. In this paper, we have considered the destination choices between home region and other regions (i.e., onward 
vs. return migration), but a more detailed analysis of the graduates' destination choices are left for further research.

Finally, the equilibrating role of graduate migration also depends on the type of individuals who are moving between the regional labor markets. Reassuringly, our findings suggest that personal unemployment increases out-migration from the region of graduation. The migration flows may not, however, have been sufficient in Finland, because the regional differences in the labor market outcomes of the highly educated labor are persistent; see also discussion in Andrews et al. (2011). Alternatively, the lower monetary returns (incl. a higher risk for unemployment) for university graduates in the periphery may simply be a compensating differential to live in places that are preferred by certain graduates (see Greenwood et al., 1991). Hence, the labor market is in equilibrium. More analysis is needed in these respects.

\section{ENDNOTES}

${ }^{1}$ Here we focus on internal migration. For international movement patterns of the highly educated, see e.g. Franklin (2003) for the US and Beine et al. (2008) for the developing countries.

${ }^{2}$ E.g., Hansen et al. (2003) investigate why so many college graduates in high-tech fields are leaving western Pennsylvania, whereas Gottlieb and Joseph (2006) study the migration and destination choices of science and technology graduates and holders of doctorates within the US in general; see also Yousefi and Rives (1987). For Finland, Kauhanen and Tervo (2002) showed that the concentration of human capital is reinforced by inter-regional migration (see also Ritsilä and Haapanen, 2003).

${ }^{3}$ Faggian et al. (2006, 2007a, 2007b) refer to onward migrants as 'repeat migrants', however, we prefer to call the group of onward and return migrants as repeat migrants 
(as in DaVanzo, 1983, and Newbold, 2001). The latter return to their home region whereas the former move to some another region.

${ }^{4}$ In addition, Détang-Dessendre and Molho (1999, 2000) consider the duration of residence spells of young men and women living in rural areas in France. Andrews et al. (2011) investigate the adjustment British labor market using a duration analysis of interregional migration, but they have excluded students from the analysis, focusing on the employed and unemployed/inactive. See also Bailey (1993) for an analysis of the US labor market.

${ }^{5}$ Hazard rates of migration are defined as the probability that a graduate will move during the next year conditional that (s)he has not moved by that time period.

${ }^{6}$ Internationally, high proportion of young cohorts enters tertiary education and graduates from it in Finland (see OECD, 2010). In terms of drop-out rates, during the academic year 2003-2004 only $4.8 \%$ of university students discontinued their studies (Statistics Finland, 2011).

${ }^{7}$ Détang-Dessendre and Molho (2000) provide evidence in support of the cumulative inertia hypothesis, but no systematic pattern of duration dependence was found in the short-distance migration of men in Détang-Dessendre and Molho (1999). Gordon and Molho (1995) reported the dominance of the cumulative stress over the cumulative inertia in their study of the moving incentives of households in the UK. Andrews, Clark and Whittaker (2011) find that much of the duration dependence, found in the raw data for Great Britain, but not all, disappears once other factors have been controlled for.

${ }^{8}$ There has been a growing interest in the decision process of families in the migration literature (e.g. Nivalainen, 2004, 2005; Deding and Filges, 2010). We use a graduate as the decision-making unit but we recognize that the family ties also matter. Thus, relevant family controls are used. 
${ }^{9}$ Note that in the proportional hazard models absolute differences in covariates imply proportional differences in the hazard rates: $\theta_{1}(t) / \theta_{2}(t)=\exp \left[\beta^{\prime}\left(X_{1}(t)-X_{2}(t)\right)\right]$. Therefore, exponentiated parameters can be interpreted as hazard ratios when the corresponding covariate increases by one unit, if all other covariates remain constant.

${ }^{10}$ The data do not reveal when individuals began their university studies. However, it is safe to follow the university graduates backwards three years because only in very rare occasions the first master's degree is completed faster than that.

${ }^{11}$ Due to data limitations home region is measured at an earlier age (14-17 years) for a smaller proportion of individuals. Alternatively, we could have defined home using information on the region of birth, see Schlottmann and Herzog (1984). However, it may be a particularly poor indicator of home if migration early in life removed individual from his or her region of birth; see discussion in Newbold (2001).

12 The survival rate gives the probability of staying in the current region until time $t$ after the beginning of the spell.

${ }^{13}$ For those individuals studying in their home region, our ten-year survival rates are similar to the 70 percent figure reported by Busch and Weigert (2010) for Germany. For those studying away from home, the survival rates are much lower than that.

${ }^{14}$ Results for each university region are available on request.

15 The average hazard rates of migration were computed as averages over observations; cf. discussion in Cameron and Trivedi (2005, p. 467). We have computed the confidence intervals for the average hazard rates using 750 bootstrap replications, where each individual is treated as a sampling unit to account for the dependence in the data; cf. Dustmann and Meghir (2005).

${ }^{16}$ One explanation might be that a graduate's family stayed in the home region during the studies, and once his or her studies are over, the graduate rejoins the family. 
Additionally, graduate might anticipate child's entry to school and wishes to return to the familiar region.

17 In the estimation same set of explanatory variables are used as above. The full estimation results are available from the authors on request.

\section{REFERENCES}

Andrews, Martyn, Ken Clark, and William Whittaker. 2011. "The Determinants of Regional Migration in Great Britain: A Duration Approach," Journal of the Royal Statistical Society: Series A, 174, 127-153.

Bailey, Adrian J. 1993. "Migration History, Migration Behaviour and Selectivity," Annals of Regional Science, 27, 315-326.

Beine, Michel, Fréderic Docquier, and Hillel Rapoport. 2008. "Brain Drain and Human Capital Formation in Developing Countries: Winners and Losers," Economic Journal, 118, 631-652.

Busch, Oliver and Benjamin Weigert. 2010. "Where Have All the Graduates Gone? Internal Cross-State Migration of Graduates in Germany 1984-2004," Annals of Regional Science, 44, 559-572.

Cameron, A. Colin and Pravin K. Trivedi. 2005. Microeconometrics: Methods and Applications. New York: Cambridge University Press.

Christiadi and Brian Cushing. 2008. "The Joint Choice of an Individual's Occupation and Destination,” Journal of Regional Science, 48, 893-919.

DaVanzo, Julie. 1983. "Repeat Migration in the United States: Who Moves Back and Who Moves on?" Review of Economics and Statistics, 65, 552-559.

Deding, Mette and Trine Filges. 2010. "Geographical Mobility of Danish Dual-Earner Couples: The Relationship between Change of Job and Change of Residence," Journal of Regional Science, 50, 615-634. 
Détang-Dessendre, Cecile and Ian Molho. 1999. ”Migration and Changing Employment Status: A Hazard Function Analysis,” Journal of Regional Science, 39, 103-123.

—. 2000. "Residence Spells and Migration: A Comparison for Men and Women," Urban Studies, 37, 247-260.

Dustmann, Christian and Costas Meghir. 2005. "Wages, Experience and Seniority." The Review of Economic Studies, 72, 77-108.

Faggian, Alessandra, Philip McCann, and Stephen Sheppard. 2006. "An Analysis of Ethnic Differences in UK Graduate Migration Behaviour," Annals of Regional Science, 40, 461-471. 2007a. "Some Evidence That Women Are More Mobile than Men: Gender

Differences in U.K. Graduate Migration Behaviour," Journal of Regional Science, $47,517-539$.

—. 2007b. "Human Capital, Higher Education and Graduate Migration: An Analysis of Scottish and Welsh Students," Urban Studies, 44, 2511-2528.

Faggian, Alessandra and Philip McCann. 2009. "Universities, Agglomerations and Graduate Human Capital Mobility," TESG Journal of Economics and Social Geography, 100, 210-223.

Franklin, Rachel S. 2003. "Migration of the Young, Single, and College Educated: 1995 to 2000," Census 2000 Special Reports, CENSR-12. Washington, DC: Bureau of the Census, U.S. Department of Commerce.

Gottlieb, Paul D. and George Joseph. 2006. "College-to-Work Migration of Technology Graduates and Holders of Doctorates within the United States," Journal of Regional Science, 46, 627-659.

Gordon, Ian R. and Ian Molho. 1995. ’Duration Dependence in Migration Behaviour: Cumulative Inertia versus Stochastic Change," Environment and Planning A, 27, 961-975. 
Greenwood, Michael J., Gary L. Hunt, Dan S. Rickman, and George I. Treyz. 1991. "Migration, Regional Equilibrium, and the Estimation of Compensating Differentials," American Economic Review, 81, 1382-1390.

Haapanen, Mika and Jari Ritsilä. 2007. "Can Migration Decisions Be Affected by Income Policy Interventions? Evidence from Finland," Regional Studies, 41, 339348.

Hansen, Susan, Carolin Ban, and Leonard Huggins. 2003. ’Explaining the 'Brain Drain' from Older Industrial Cities: The Pittsburgh Region," Economic Development Quarterly, 17, 132-147.

Helderman, Amanda C., Maarten van Ham, and Clara H. Mulder. 2006. "Migration and Home Ownership," Tijdschrift voor Economische en Sociale Geografie, 97, 111125.

Herzog, Henry W. Jr., Alan M. Schlottmann, and Thomas Boehm. 1993. "Migration as Spatial Job-Search: A Survey of Empirical Findings," Regional Studies, 27, 327340.

Huff, James and William Clark 1978. "Cumulative Stress and Cumulative Inertia: A Behavioural Model of the Decision to Move, Environment and Planning A, 10, $1101-1119$.

Jauhiainen, Signe. 2010. "Education and Employment Opportunities: Migration of University Graduates in Finnish Regions," in S. Jauhiainen (2010), Studies on Human Capital Flows and Spatial Labour Markets. Jyväskylä Studies in Business and Economics 94, University of Jyväskylä, Jyväskylä, pp. 30-47.

Kangasharju, Aki and Sari Pekkala. 2004. "Increasing Regional Disparities in the 1990s: The Finnish Experience," Regional Studies, 38, 255-267.

Kauhanen, Merja and Hannu Tervo. (2002). "Who Moves to Depressed Regions? An Analysis of Migration Streams in Finland in the 1990s," International Regional Science Review, 25, 200-218. 
Meyer, Bruce D. 1990. "Unemployment Insurance and Unemployment Spells," Econometrica, 58, 757-782.

Milne, William J. 1993. "Macroeconomic Influences on Migration," Regional Studies, $27,365-373$.

Mincer, Jacob. 1978. "Family Migration Decisions," Journal of Political Economy, 86, $749-773$.

Ministry of Education. 2005. OECD Thematic Review of Tertiary Education: Country Background Report for Finland, Publications of the Ministry of Education, Finland, 2005:38

2009. "KOTA Online Database Service." Statistical data on universities and fields of education from 1981, Finland.

Molho, Ian. 1995. "Migrant Inertia, Accessibility and Local Unemployment," Economica, 62, 123-132.

Narendranathan, Wiji and Mark Stewart. 1993. "Modelling the Probability of Leaving Unemployment: Competing Risks Models with Flexible Base-Line Hazards," Applied Statistics, 42, 63-83.

Newbold, K. Bruce. 2001. "Counting Migrants and Migrations: Comparing Lifetime and Fixed-Interval Return and Onward Migration," Economic Geography, 77, 2340.

Nivalainen, Satu. 2004. "Determinants of Family Migration: Short Moves vs. Long Moves," Journal of Population Economics, 17, 157-175.

- 2005. "Interregional Migration and Post-Move Employment in Two-Earner Families: Evidence from Finland," Regional Studies, 39, 891-907.

OECD. 2010. OECD Factbook 2010: Economic, Environmental and Social Statistics. OECD Publishing.

Pekkala, Sari and Hannu Tervo. 2002. "Unemployment and Migration: Does Moving Help?" Scandinavian Journal of Economics, 104, 621-639. 
Pissarides, Christopher A. and Jonathan Wadsworth. 1989. "Unemployment and the Inter-Regional Mobility of Labour,” Economic Journal, 99, 739-755.

Plane, David A. and Jason R. Jurjevich. 2009. "Ties That No Longer Bind? The Patterns and Repercussions of Age-Articulated Migration," Professional Geographer, 61, 420.

Prentice, Ross L. and Lynn A. Gloeckler. 1978. "Regression Analysis of Grouped Survival Data with Application to Breast Cancer Data," Biometrics, 34, 57-67.

Rickman, Dan S. and Shane D. Rickman. Forthcoming. "Population Growth in HighAmenity Nonmetropolitan Areas: What's the Prognosis?" Journal of Regional Science.

Ritsilä, Jari and Mika Haapanen. 2003. ”Where Do the Highly Educated Migrate? Micro-Level Evidence from Finland," International Review of Applied Economics, $17,437-448$.

Romani, Javier, Jordi Suriñach, and Manuel Artís. 2003. "Are Commuting and Residential Mobility Decisions Simultaneous? The Case of Catalonia, Spain," Regional Studies, 37, 813-826.

Saarenmaa, Kaisa, Katja Saari, and Vesa Virtanen. 2010. ”Student Survey 2010. Higher Education Students' Income and Studies (in Finnish)," Publications of the Ministry of Education and Culture, Finland, 2010:18.

Schlottmann, Alan M. and Henry W. Jr. Herzog. 1984. "Career and Geographic Mobility Interactions: Implications for the Age Selectivity of Migration,” Journal of Human Resources, 19, 72-86.

Sjaastad, Larry A. 1962. "The Costs and Returns of Human Migration," Journal of Political Economy, 70 (Supplement), 80-93.

Statistics Finland. 2011. "Discontinuation of Education," Helsinki: Statistics Finland (epublication). http://www.stat.fi/til//kkesk/index_en.html 
Sueyoshi, Glenn T. 1995. "A Class of Binary Response Models for Grouped Duration Data," Journal of Applied Econometrics, 10, 411-431.

Tervo, Hannu. 2000. ”Migration and Labour Market Adjustment: Empirical Evidence from Finland 1985-90," International Review of Applied Economics, 14, 343-360.

—. 2005. "Regional Policy Lessons from Finland," in Daniel Felsenstein and Boris A. Portnov (eds.), Regional Disparities in Small Countries. Springer: Advances in Spatial Science, Chapter 15, pp. 267-282.

Van Den Berg, Gerard J. 2001. "Duration Models: Specification, Identification, and Multiple Durations," in James Heckman and Edward Leamer (eds.), Handbook of Econometrics. Volume V, North-Holland, Amsterdam, Chapter 55, pp. 3381-3460. Venhorst, Victor, Jouke van Dijk, and Leo van Wissen. 2011. ”An Analysis of Trends in Spatial Mobility of Dutch Graduates," Spatial Economic Analysis, 6, 57-82.

Winters, John V. 2011. "Why Are Smart Cities Growing? Who Moves and Who Stays," Journal of Regional Science, 51, 253-270.

Wooldridge, Jeffrey M. 2002. Econometric Analysis of Cross Section and Panel Data. Cambridge, Massachusetts: The MIT Press.

Yousefi, Mahmood and Janet Rives. 1987. ”Migration Behavior of College Graduates: An Empirical Analysis," Journal of Behavioral Economics, 16, 35-49. 


\begin{tabular}{|c|c|}
\hline Covariate & Description \\
\hline \multicolumn{2}{|c|}{ Personal characteristics } \\
\hline Female & 1 if female, 0 if male \\
\hline $\operatorname{Age}^{\dagger}$ & Age in years \\
\hline $\mathrm{Age}^{\dagger}$ & Age squared divided by 100 \\
\hline Post-grad. educ. ${ }^{\dagger}$ & 1 if a person has licentiate or doctoral degree, 0 otherwise \\
\hline Humanities $^{\dagger}$ & 1 if field of education is humanities or arts, 0 otherwise \\
\hline Trade $^{\dagger}$ & 1 if educ. field is business or social sciences, 0 otherwise \\
\hline Technical $^{\dagger}$ & 1 if educ. field is technology or natural sc., 0 otherwise (ref. category) \\
\hline Health $^{\dagger}$ & 1 if educ. field is health or welfare, 0 otherwise \\
\hline Sports $^{\dagger}$ & 1 if educ. field is sports, 0 otherwise \\
\hline Other educ. ${ }^{\dagger}$ & $\begin{array}{l}1 \text { if educ. field is teacher educ. or educ. science, agriculture or forestry, or } \\
\text { not known, } 0 \text { otherwise }\end{array}$ \\
\hline \multicolumn{2}{|c|}{ Household characteristics } \\
\hline Married $^{\dagger}$ & 1 if married or cohabiting, 0 otherwise \\
\hline Sp. educ. ${ }^{\dagger}$ & $\begin{array}{l}\text { Spouse's level of education ( } 0 \text { if no spouse, } 1 \text { if comprehensive educ.,..., } \\
5 \text { if higher tertiary educ.) }\end{array}$ \\
\hline Sp. empl..$^{\dagger}$ & 1 if spouse is employed, 0 otherwise \\
\hline Sp. income ${ }^{\dagger}$ & Annual income of spouse, $10,000 €$ \\
\hline No children ${ }^{\dagger}$ & 1 if no children under 18 years in the family, 0 otherwise (ref. category) \\
\hline All children under $7^{\dagger}$ & 1 if all children under 7 years, 0 otherwise \\
\hline School-aged children ${ }^{\dagger}$ & 1 if $7-18$-year-old children in the family, 0 otherwise \\
\hline Not home-owner ${ }^{\dagger}$ & 1 if person is not owner of a house or a flat, 0 otherwise (ref. category) \\
\hline House-owner $^{\dagger}$ & 1 if owner-occupier of a house, 0 otherwise \\
\hline Flat-owner $^{\dagger}$ & 1 if owner-occupier of a flat, 0 otherwise \\
\hline \multicolumn{2}{|c|}{ Labor market characteristics } \\
\hline Employed $^{\dagger}$ & 1 if employed during the last week of year, 0 otherwise (ref. category) \\
\hline Unempl. $^{\dagger}$ & 1 if unemployed during the last week of year, 0 otherwise \\
\hline Out-of-labor ${ }^{\dagger}$ & 1 if person is out of labor force, 0 otherwise \\
\hline Months employed ${ }^{\dagger}$ & Number of months employed (0-12) \\
\hline Earnings $^{\dagger}{ }^{\top}$ & Annual earnings subject to state taxation, $10,000 €$ \\
\hline Unempl. rate ${ }^{\dagger}$ & Unemployment rate in travel-to-work area, $\%$ \\
\hline Commuting $^{\dagger}$ & $\begin{array}{l}1 \text { if commuting from the municipality of residence during the last week } \\
\text { of a year, } 0 \text { otherwise }\end{array}$ \\
\hline \multicolumn{2}{|r|}{ (1) } \\
\hline Helsinki & $\begin{array}{l}1 \text { if living in the NUTS } 3 \text { region Uusimaa (variable is named after the } \\
\text { main university in the region), } 0 \text { otherwise }\end{array}$ \\
\hline Turku & 1 if living in Varsinais-Suomi, 0 otherwise \\
\hline Tampere & 1 if living in Pirkanmaa, 0 otherwise \\
\hline Lappeenranta & 1 if living in Etelä-Karjala, 0 otherwise \\
\hline Kuopio & 1 if living in Pohjois-Savo, 0 otherwise \\
\hline Joensuu & 1 if living in Pohjois-Karjala, 0 otherwise \\
\hline Jyväskylä & 1 if living in Keski-Suomi, 0 otherwise \\
\hline Vaasa & 1 if living in Pohjanmaa, 0 otherwise \\
\hline Oulu & 1 if living in Pohjois-Pohjanmaa, 0 otherwise \\
\hline Rovaniemi & 1 if living in Lappi, 0 otherwise \\
\hline Other regions & 1 if living in another NUTS3 region, 0 otherwise \\
\hline \multicolumn{2}{|c|}{ Origin-specific characteristics ${ }^{(\mathrm{i}}$} \\
\hline Living in the origin & 1 if living in NUTS3 region where resided at the age of 18,0 otherwise \\
\hline Unempl. rate $(\mathrm{O})^{\dagger}$ & Unemployment rate currently in the origin NUTS3 region, \% \\
\hline $\ln ($ distance $)$ & $\ln$ (road-line distance between the current and origin location, $\mathrm{km}$ ) \\
\hline
\end{tabular}

Notes: Variables are measured on a year before the migration decision is annually made. ${ }^{*}$ Timevarying covariate during the residence spell. i) The origin is the region where the individual resided at the age of 18 years. Origin-specific characteristics also include unreported 18 NUTS3 regional dummies (see Appendix, Figure A1). 
TABLE 2: Life-Table Estimates of Residence Duration by Origin

\begin{tabular}{|c|c|c|c|c|c|c|c|}
\hline \multirow[b]{2}{*}{$\begin{array}{c}\text { Interval } \\
\text { (years) }\end{array}$} & \multicolumn{3}{|c|}{ Studying at Home } & \multicolumn{4}{|c|}{ Studying Away } \\
\hline & $\begin{array}{l}\text { Number } \\
\text { of Obs. }\end{array}$ & $\begin{array}{l}\text { Hazard } \\
\text { Rate, \% }\end{array}$ & $\begin{array}{l}\text { Survival } \\
\text { Rate, \% }\end{array}$ & $\begin{array}{l}\text { Number } \\
\text { of Obs. }\end{array}$ & $\begin{array}{l}\text { Hazard } \\
\text { Rate, \% }\end{array}$ & $\begin{array}{l}\text { Survival } \\
\text { Rate, } \%\end{array}$ & $\begin{array}{c}\% \text { of } \\
\text { Migrants } \\
\text { Returning }\end{array}$ \\
\hline-2 & 2699 & 1.37 & 98.6 & 1674 & 4.96 & 95.0 & 49.4 \\
\hline-1 & 2662 & 3.01 & 95.7 & 1591 & 9.37 & 86.1 & 39.0 \\
\hline $0^{(\mathrm{i}}$ & 2582 & 7.55 & 88.4 & 1442 & 18.72 & 70.0 & 38.5 \\
\hline 1 & 2387 & 5.66 & 83.4 & 1172 & 10.67 & 62.5 & 33.6 \\
\hline 2 & 2038 & 3.29 & 80.7 & 915 & 5.57 & 59.1 & 45.1 \\
\hline 3 & 1791 & 2.85 & 78.4 & 741 & 3.78 & 56.8 & 39.2 \\
\hline 4 & 1550 & 2.19 & 76.7 & 604 & 3.15 & 55.0 & 52.7 \\
\hline 5 & 1352 & 2.44 & 74.8 & 490 & 3.88 & 52.9 & 31.4 \\
\hline 6 & 1123 & 1.51 & 73.7 & 367 & 4.63 & 50.5 & 52.9 \\
\hline 7 & 938 & 1.17 & 72.8 & 285 & 1.75 & 49.6 & 20.0 \\
\hline 8 & 776 & 0.77 & 72.3 & 227 & 1.32 & 48.9 & 33.3 \\
\hline 9 & 648 & 0.93 & 71.6 & 176 & 1.70 & 48.1 & 0.0 \\
\hline 10 & 508 & 0.59 & 71.2 & 131 & 0.00 & 48.1 & - \\
\hline 11 & 381 & 0.52 & 70.8 & 91 & 1.10 & 47.6 & 100.0 \\
\hline 12 & 251 & 0.40 & 70.5 & 55 & 0.00 & 47.6 & - \\
\hline 13 & 138 & 0.72 & 70.0 & 28 & 0.00 & 47.6 & - \\
\hline
\end{tabular}

Notes: i) Graduation year. Log-rank test rejects the equality of the survivor functions: $\chi^{2}=295.84$ with d.f. $=1$ (p-value $<0.001)$.

TABLE 3: Survival Rates (\%) at Selected Intervals by Origin and Region of Studies

\begin{tabular}{cccccc}
\hline \hline \multirow{2}{*}{$\begin{array}{c}\text { Interval } \\
\text { (years) }\end{array}$} & \multicolumn{2}{c}{ Studying at Home, in ${ }^{\text {(ii }}$} & & \multicolumn{2}{c}{ Studying Away, in ${ }^{\text {(iii }}$} \\
\cline { 2 - 3 } \cline { 5 - 6 } & $\begin{array}{c}\text { Helsinki } \\
\text { Region }\end{array}$ & $\begin{array}{c}\text { Some Other } \\
\text { Region }\end{array}$ & & $\begin{array}{c}\text { Helsinki } \\
\text { Region }\end{array}$ & $\begin{array}{c}\text { Some Other } \\
\text { Region }\end{array}$ \\
\hline-2 & $99.5 \%$ & $97.9 \%$ & & $98.2 \%$ & $92.4 \%$ \\
$0^{(\mathrm{i}}$ & $96.8 \%$ & $80.8 \%$ & & $85.8 \%$ & $56.6 \%$ \\
5 & $90.2 \%$ & $61.0 \%$ & & $71.5 \%$ & $36.9 \%$ \\
10 & $87.4 \%$ & $56.5 \%$ & & $64.4 \%$ & $33.9 \%$ \\
13 & $85.3 \%$ & $56.2 \%$ & & $63.3 \%$ & $33.9 \%$ \\
\hline \hline
\end{tabular}

Notes: i) Graduation year. ii) and iii) Log-rank test rejects the equality of the survivor functions in both cases: $\chi^{2}=344.08$ and 300.82 (p-values $<0.001$ ). Full set of survival rates are available on request. 
TABLE 4: Discrete-Time Duration Models for Migration

\begin{tabular}{|c|c|c|c|c|c|c|}
\hline \multirow{2}{*}{ Covariate } & \multirow{2}{*}{\multicolumn{2}{|c|}{ Studying at Home }} & \multicolumn{4}{|c|}{ Studying Away } \\
\hline & & & \multicolumn{2}{|c|}{ Onward Migrate } & \multicolumn{2}{|c|}{ Return Migrate } \\
\hline \multicolumn{7}{|c|}{ Personal characteristics } \\
\hline Female & $0.149 *$ & $(0.086)$ & -0.108 & $(0.110)$ & -0.080 & $(0.134)$ \\
\hline Age & $0.527 * * *$ & $(0.183)$ & 0.219 & $(0.180)$ & 0.333 & $(0.265)$ \\
\hline Age2 & $-0.874 * * *$ & $(0.313)$ & -0.356 & $(0.307)$ & -0.642 & $(0.462)$ \\
\hline Post-grad. educ. & $1.061 * * *$ & $(0.205)$ & -0.303 & $(0.602)$ & $0.938 *$ & $(0.492)$ \\
\hline Humanities & 0.090 & $(0.150)$ & $0.578 * * *$ & $(0.172)$ & 0.016 & $(0.215)$ \\
\hline Trade & $0.245^{* *}$ & $(0.122)$ & $0.312 *$ & $(0.164)$ & 0.021 & $(0.202)$ \\
\hline Health & $0.466 * * *$ & $(0.162)$ & $0.720 * * *$ & $(0.230)$ & $0.491 *$ & $(0.255)$ \\
\hline Sports & $1.522 * * *$ & $(0.284)$ & $0.763 * *$ & $(0.381)$ & 0.441 & $(0.460)$ \\
\hline Other educ. & 0.175 & $(0.144)$ & $0.511 * * *$ & $(0.183)$ & 0.087 & $(0.232)$ \\
\hline \multicolumn{7}{|c|}{ Household characteristics } \\
\hline Married & $-0.616^{* * *}$ & $(0.183)$ & -0.294 & $(0.193)$ & 0.130 & $(0.219)$ \\
\hline Sp. educ. & $0.133 * * *$ & $(0.046)$ & $0.096 *$ & $(0.058)$ & -0.098 & $(0.064)$ \\
\hline Sp. empl. & $-0.249 *$ & $(0.148)$ & $-0.431 * * *$ & $(0.162)$ & -0.130 & $(0.191)$ \\
\hline Sp. income & $-0.207 * * *$ & $(0.061)$ & -0.037 & $(0.076)$ & -0.072 & $(0.069)$ \\
\hline All children under 7 & 0.034 & $(0.143)$ & -0.211 & $(0.157)$ & $0.505 * * *$ & $(0.182)$ \\
\hline \multicolumn{7}{|l|}{ School-aged } \\
\hline children & -0.513 & $(0.382)$ & $-0.787 * *$ & $(0.369)$ & -0.918 & $(0.602)$ \\
\hline House-owner & $-0.558 * * *$ & $(0.113)$ & $-1.980 * * *$ & $(0.490)$ & -0.574 & $(0.376)$ \\
\hline Flat-owner & $-0.311 * * *$ & $(0.094)$ & $-0.640 * * *$ & $(0.143)$ & $-0.325^{*}$ & $(0.173)$ \\
\hline \multicolumn{7}{|c|}{ Labor market characteristics } \\
\hline Unempl. & -0.014 & $(0.210)$ & $0.531 * *$ & $(0.253)$ & $0.592 *$ & $(0.344)$ \\
\hline Out-of-labor & $0.227 *$ & $(0.129)$ & $0.366 * *$ & $(0.156)$ & $0.574 * * *$ & $(0.184)$ \\
\hline Months employed & -0.012 & $(0.012)$ & -0.021 & $(0.016)$ & $-0.039 *$ & $(0.020)$ \\
\hline Earnings & -0.066 & $(0.041)$ & -0.071 & $(0.062)$ & -0.046 & $(0.064)$ \\
\hline Unempl. rate & -0.002 & $(0.024)$ & 0.023 & $(0.065)$ & $0.135^{*}$ & $(0.071)$ \\
\hline \multirow{2}{*}{\multicolumn{7}{|c|}{ NUTS3 region ${ }^{\mathrm{i}}$}} \\
\hline & & & & & & \\
\hline Turku & $1.330 * * *$ & $(0.141)$ & $0.868 * * *$ & $(0.257)$ & 0.272 & $(0.283)$ \\
\hline Tampere & $1.514 * * *$ & $(0.179)$ & $1.196 * * *$ & $(0.370)$ & -0.359 & $(0.407)$ \\
\hline Lappeenranta & $2.219 * * *$ & $(0.271)$ & $2.194 * * *$ & $(0.539)$ & 0.520 & $(0.606)$ \\
\hline Kuopio & $1.597 * * *$ & $(0.282)$ & $1.405 * * *$ & $(0.475)$ & 0.164 & $(0.536)$ \\
\hline Joensuu & $1.945^{* * *}$ & $(0.291)$ & $1.320 * *$ & $(0.569)$ & 0.063 & $(0.657)$ \\
\hline Jyväskylä & $1.805 * * *$ & $(0.242)$ & $1.488 * * *$ & $(0.492)$ & -0.489 & $(0.558)$ \\
\hline Vaasa & $1.301 * * *$ & $(0.227)$ & $1.603 * * *$ & $(0.267)$ & $0.821 * *$ & $(0.359)$ \\
\hline Oulu & $1.305 * * *$ & $(0.193)$ & $0.768^{*}$ & $(0.448)$ & 0.077 & $(0.514)$ \\
\hline Rovaniemi & $3.004 * * *$ & $(0.343)$ & $1.441 * *$ & $(0.722)$ & 0.674 & $(0.850)$ \\
\hline Other regions & $1.965 * * *$ & $(0.302)$ & $1.095 *$ & $(0.596)$ & 0.258 & $(0.675)$ \\
\hline
\end{tabular}


TABLE 4: (Continued)

\begin{tabular}{|c|c|c|c|c|c|c|}
\hline \multirow{2}{*}{ Covariate } & \multirow{2}{*}{\multicolumn{2}{|c|}{ Studying at Home }} & \multicolumn{4}{|c|}{ Studying Away } \\
\hline & & & \multicolumn{2}{|c|}{ Onward Migrate } & \multicolumn{2}{|c|}{ Return Migrate } \\
\hline \multicolumn{3}{|c|}{ Origin-specific characteristics } & & & & \\
\hline \multicolumn{3}{|c|}{ Unempl. rate $(\mathrm{O})$} & 0.065 & $(0.063)$ & -0.116 & $(0.084)$ \\
\hline \multicolumn{3}{|c|}{$\ln ($ distance $)$} & $0.330 * * *$ & $(0.118)$ & -0.107 & $(0.148)$ \\
\hline \multicolumn{7}{|c|}{ NUTS3 region of origin ${ }^{(\mathrm{i}}$} \\
\hline \multicolumn{3}{|c|}{ Turku (O) } & 0.645 & $(0.438)$ & -0.149 & $(0.360)$ \\
\hline \multicolumn{3}{|l|}{ Tampere $(\mathrm{O})$} & 0.506 & $(0.485)$ & 0.128 & $(0.501)$ \\
\hline \multicolumn{3}{|l|}{ Lappeenranta $(\mathrm{O})$} & 0.282 & $(0.587)$ & -0.369 & $(0.705)$ \\
\hline \multicolumn{3}{|l|}{ Kuopio $(\mathrm{O})$} & 0.404 & $(0.568)$ & -0.579 & $(0.682)$ \\
\hline \multicolumn{3}{|l|}{ Joensuu (O) } & 0.288 & $(0.742)$ & -0.521 & $(1.004)$ \\
\hline \multicolumn{3}{|l|}{ Jyväskylä (O) } & 0.497 & $(0.584)$ & -0.419 & $(0.694)$ \\
\hline \multicolumn{3}{|l|}{ Vaasa $(\mathrm{O})$} & 0.177 & $(0.470)$ & -0.371 & $(0.344)$ \\
\hline \multicolumn{3}{|l|}{ Oulu (O) } & 0.068 & $(0.526)$ & 0.050 & $(0.580)$ \\
\hline \multicolumn{3}{|l|}{ Rovaniemi (O) } & -0.133 & $(0.826)$ & -1.170 & $(1.075)$ \\
\hline \multicolumn{3}{|l|}{ Itä-Uusimaa (O) } & $1.126^{* *}$ & $(0.520)$ & -0.311 & $(0.426)$ \\
\hline \multicolumn{3}{|l|}{ Satakunta $(\mathrm{O})$} & 0.721 & $(0.564)$ & 0.117 & $(0.636)$ \\
\hline \multicolumn{3}{|l|}{ Kanta-Häme (O) } & $1.071 * *$ & $(0.425)$ & $-1.907 * * *$ & $(0.605)$ \\
\hline \multicolumn{3}{|l|}{ Päijät-Häme (O) } & 0.678 & $(0.545)$ & -0.435 & $(0.626)$ \\
\hline \multicolumn{3}{|l|}{ Kymenlaakso (O) } & 0.543 & $(0.544)$ & -0.575 & $(0.627)$ \\
\hline \multicolumn{3}{|l|}{ Etelä-Savo (O) } & 0.771 & (0.604) & -0.517 & $(0.736)$ \\
\hline \multicolumn{3}{|l|}{ Etelä-Pohjanmaa (O) } & 0.620 & $(0.431)$ & -0.450 & $(0.421)$ \\
\hline \multicolumn{3}{|l|}{ Keski-Pohjanmaa (O) } & $0.836^{*}$ & $(0.476)$ & $-1.402 * *$ & $(0.644)$ \\
\hline \multicolumn{7}{|l|}{ Baseline hazard } \\
\hline$\alpha_{-2}$ & $-13.158 * * *$ & $(2.612)$ & $-12.190 * * *$ & $(2.841)$ & $-6.849 *$ & (3.993) \\
\hline$\alpha_{-1}$ & $-12.306 * * *$ & $(2.667)$ & $-11.207 * * *$ & $(2.881)$ & -6.413 & $(4.021)$ \\
\hline$\alpha_{0}$ & $-11.305 * * *$ & $(2.673)$ & $-10.193 * * *$ & $(2.893)$ & -5.457 & (4.019) \\
\hline$\alpha_{1}$ & $-11.453 * * *$ & $(2.681)$ & $-10.356 * * *$ & (2.898) & -5.863 & $(4.034)$ \\
\hline$\alpha_{2}$ & $-11.941 * * *$ & $(2.687)$ & $-10.925 * * *$ & (2.908) & -5.943 & $(4.016)$ \\
\hline$\alpha_{3}$ & $-12.049 * * *$ & (2.689) & $-11.036 * * *$ & (2.908) & -6.369 & $(4.026)$ \\
\hline$\gamma_{0}$ & $-12.181 * * *$ & (2.698) & $-11.054 * * *$ & (2.888) & -6.105 & $(4.058)$ \\
\hline$\gamma_{1}$ & -0.267 & $(0.164)$ & 0.025 & $(0.223)$ & -0.373 & $(0.315)$ \\
\hline Year dummies & Yes & & $\mathrm{Ye}$ & & & \\
\hline Log-likelihood & $-2,567$ & .89 & $-1,566$ & & $-1,13$ & 7.75 \\
\hline $\begin{array}{l}\text { LR-test for random } \\
\text { effects }\end{array}$ & $\mathrm{p}=0$ & 491 & $\mathrm{p}=0$ & & $p=0$ & .436 \\
\hline Number of obs. & 21,8 & & 9,98 & & & \\
\hline
\end{tabular}

Notes: Parameter estimates are given, followed by robust standard errors in parenthesis that allow for clustering at the individual-level. Definitions of variables and reference categories are given in Table $1 . *$, $* *$, *** denote significance at $10 \%, 5 \%, 1 \%$ significance levels. i) University NUTS3 regions are renamed after the municipality of the university; Helsinki is the reference region. 


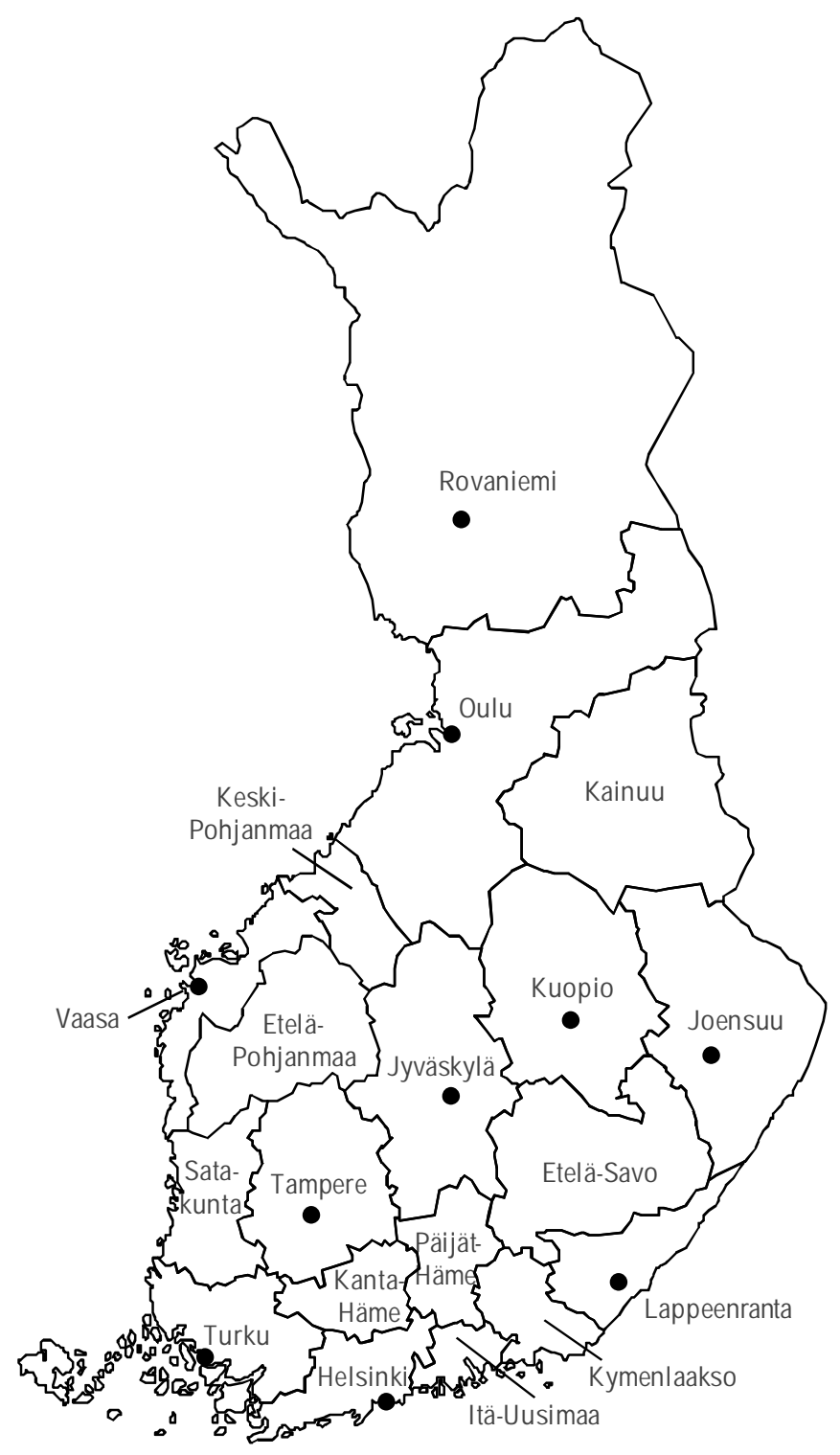

FIGURE A1: University Municipalities and NUTS3 Regions in Finland. Notes: NUTS3 region of the university municipality in parenthesis: Helsinki (Uusimaa), Turku (Varsinais-Suomi), Tampere (Pirkanmaa), Lappeenranta (Etelä-Karjala), Kuopio (Pohjois-Savo), Joensuu (Pohjois-Karjala), Jyväskylä (Keski-Suomi), Vaasa (Pohjanmaa), Oulu (Pohjois-Pohjanmaa) and Rovaniemi (Lappi). 


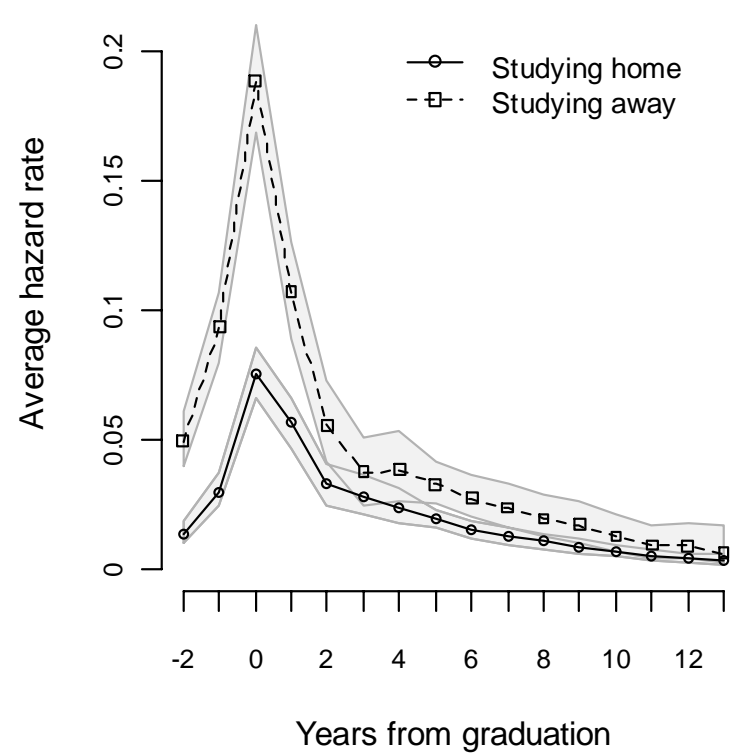

a) For all university graduates

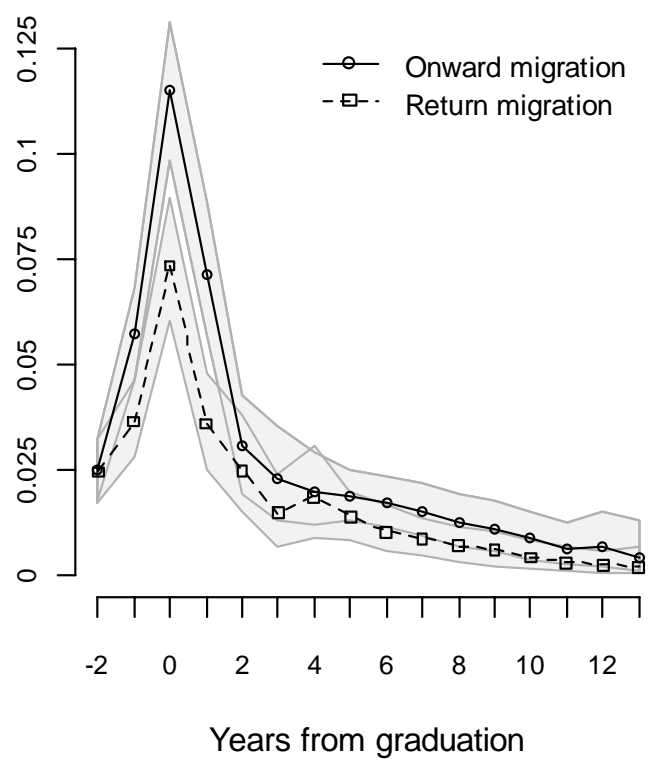

b) For graduates away from home

FIGURE 1: Average Hazard Rates of Migration a) for University Graduates b) for University Graduates Studying Away from Home (cf. Table 4). Notes: Shading indicates $95 \%$ confidence intervals. 


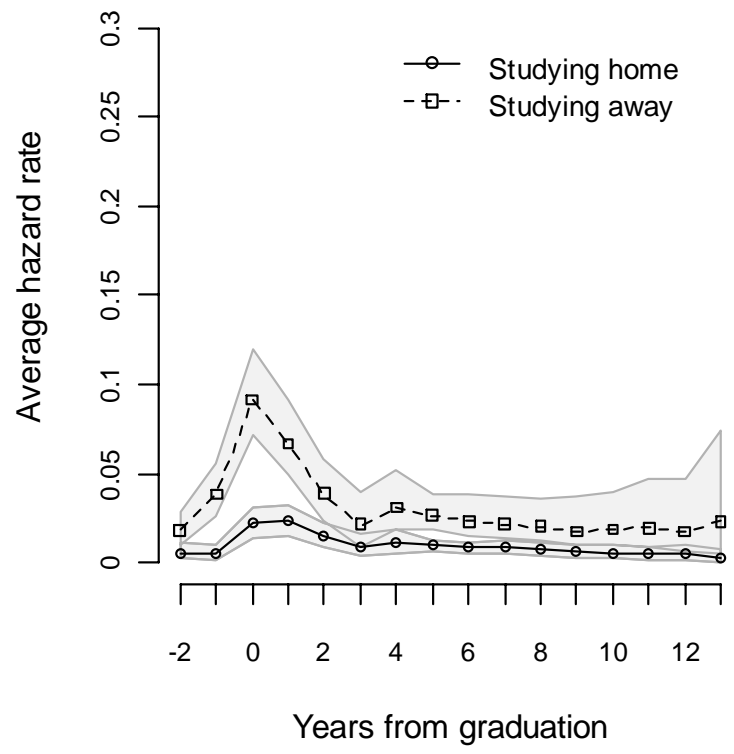

a) Studying in Helsinki region

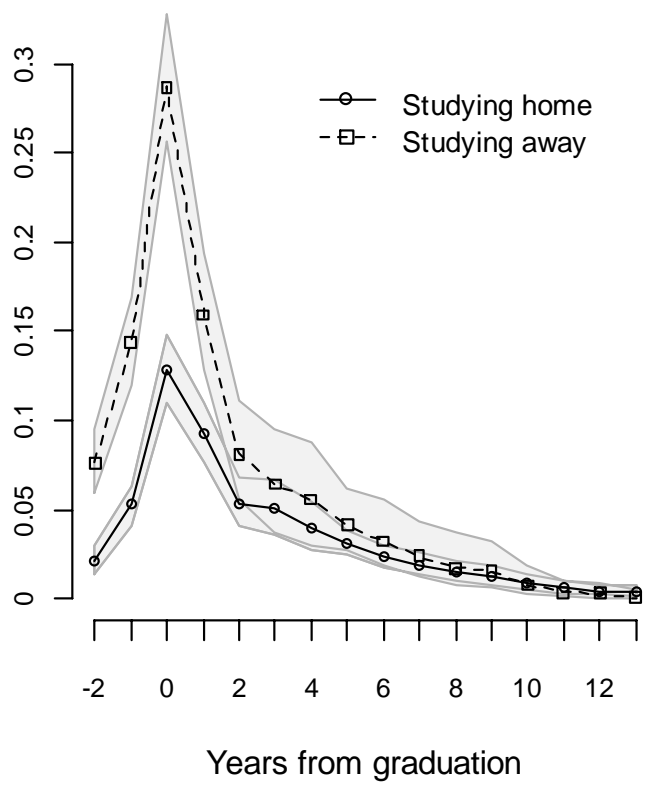

b) Studying in other regions

FIGURE 2: Average Hazard Rates of Migration for University Graduates Studying in a) Helsinki NUTS3 Region; b) Other Regions. Notes: Shading indicates 95\% confidence intervals. 


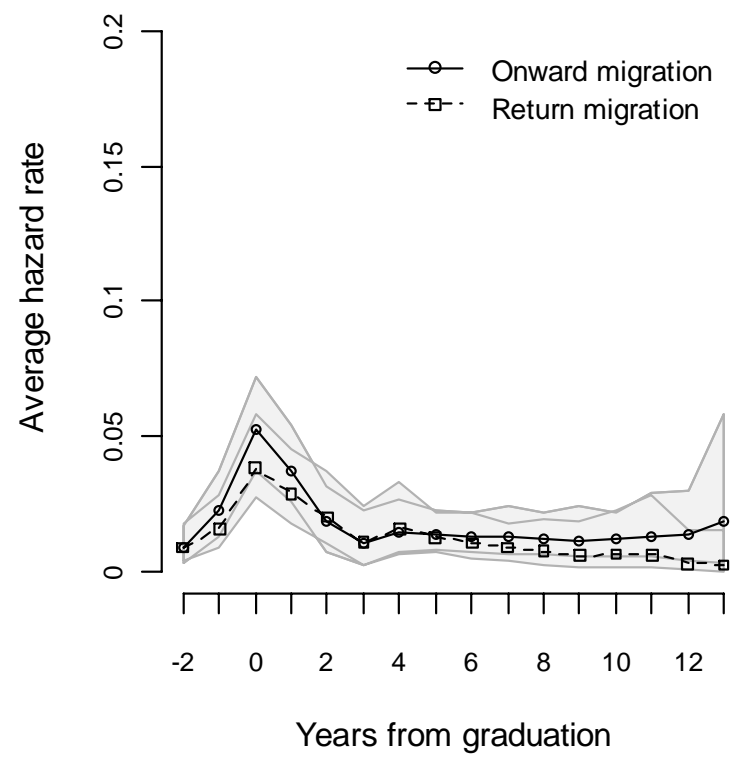

a) Studying in Helsinki region

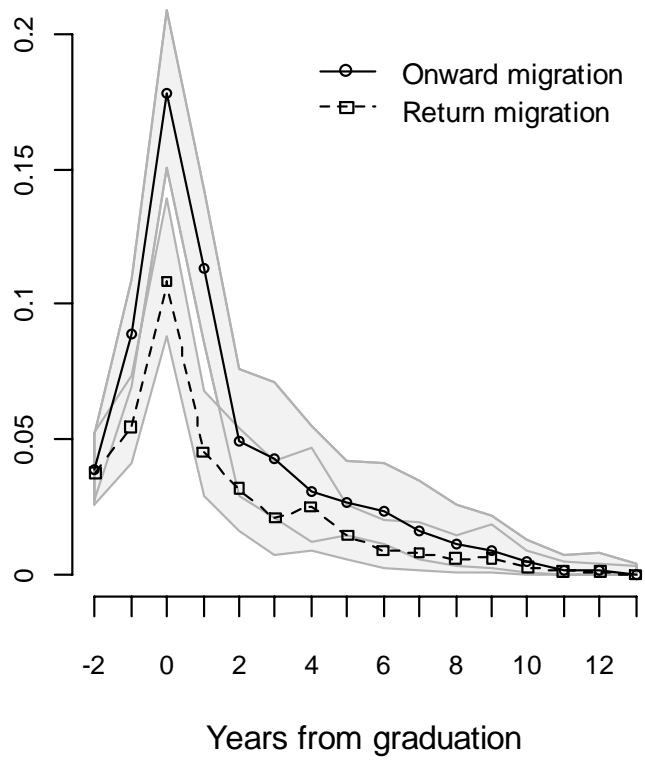

b) Studying in other regions

FIGURE 3: Average Hazard Rates of Onward and Return Migration for University Graduates Studying Away from Home in a) Helsinki NUTS3 Region; b) Other Regions. Notes: Shading indicates $95 \%$ confidence intervals. 